Volume 3, Nomor 1, 2020, hlm. 41-56

P-ISSN: 2622-2280 | E-ISSN: 2622-4658

https://ejurnal.iiq.ac.id/index.php/alfanar

DOI: $10.33511 /$ alfanar.v3n1.41-56

\title{
Konsep Environmentalisme dalam Al-Qur'an
}

(Studi Tafsir Al-Misbah Karya M. Quraish Shihab)

\section{Muhammad Saiful Anam}

Sekolah Pascasarjana UIN Syarif Hidayatullah Jakarta

saifulanamalqudsy@gmail.com

\begin{abstract}
Natural damage that occurred in almost all parts of the world in the last decade has become a hot issue and makes it a cause for concern. Environmental problems invite and ask various sides to give their best contributionsto effort in saving nature. Not simply for ecological scientists, but the Quran interpreters also contributed to rescue for nature. Since the $\sigma^{\text {th }}$ century, Islam has been present in giving attention to the environment. By means of the Quran, Islam has also given the task to humans who are caliphs on earth to be fair and not do damage to nature. This problem leads to the understanding of the Quran interpreters including M. Quraish Shihab. In tafsir al-Mișbạh, he included the concept of environmentalism to clarify verses about the environment. His idea in providing solutions related to environmental problems is seen through efforts that can be made in the form of making legal regulations; establish cooperation between goverments, companies, communities and academics; maintaining natural recources;

reforestation; and be friendly to the environment.
\end{abstract}

Keywords: Environmentalism, Nature, al-Misbah

Abstrak

Kerusakan alam yang terjadi pada hampir semua belahan dunia dalam dekade terakhir ini telah menjadi isu hangat dan menjadikannya sebagai fokus perhatian. Permasalahan lingkungan mengundang dan meminta berbagai pihak untuk memberikan kontribusi terbaik mereka dalam upaya penyelamatan terhadap alam. Tidak hanya bagi para ilmuwan ekologi, tetapi para penafsir Qur'an juga berkontribusi untuk menyelamatkan alam. Sejak abad ke-6, Islam telah hadir dalam memberikan perhatian terhadap lingkungan. Melalui Al-Qur'an, Islam juga telah memberikan tugas kepada manusia sebagai khalifah di atas bumi untuk bersikap adil dan tidak merusak alam. Permasalahan ini mengantarkan pada pemahaman para penafsir Al-Qur'an diantaranya M. Quraish Shihab. Dalam tafsir al-Misbah, dia memasukkan konsep environmentalisme untuk menjelaskan ayat-ayat tentang lingkungan. Idenya dalam memberikan solusi terkait permasalahan lingkungan dapat dilihat melalui upaya yang dapat dilakukan untuk membuat peraturan hukum; menjalin kerja sama antara pemerintah, perusahaan, masyarakat dan akademisi; menjaga sumber daya alam; reboisasi; dan ramah terhadap lingkunganKeywords: environmentalism, nature, al-Misbah

Kata Kunci: Environmentalisme, Alam, al-Misbah 


\section{PENDAHULUAN}

Kelestarian lingkungan merupakan hal yang sangat berpengaruh bagi kelangsungan kehidupan manusia. ${ }^{1}$ Hal ini terlihat dari kebergantungan kebutuhan primer manusia yang terdiri dari sandang, papan dan pangan merupakan materi yang berasal dari alam sekitar. ${ }^{2}$ Eksistensi alam juga berkontribusi bagi kelangsungan hidup bagi seluruh makhluk di atas bumi - terdiri dari tumbuh-tumbuhan, hewan dan lain sebagainya - yang menunjukkan bahwa manusia bukanlah makhluk yang sendirian dalam hal membutuhkan alam. Namun, dalam berbagai hal manusia kurang menyadari bahwa keberadaan alam di atas bumi tidaklah membutuhkan manusia untuk menjaga kelangsungan hidup mereka, akan tetapi manusialah sendiri yang membutuhkan makhluk hidup lain untuk menyambung kelangsungan hidupnya. Sehingga eksploitasi alam sering terjadi dimana-mana sebagai akibat dari tindakan manusia yang kerap tidak terkontrol dalam memanfaatkan alam.

Permasalahan lingkungan saat ini sangatlah banyak dan beragam setiap harinya. Fenomena-fenomena kontemporer seperti Green House Effect, Acid Rain, Heat Island, The Hole in the Sky dan lain sebagainya merupakan tanda bahwa sedikit demi sedikit alam sudah mengalami kemusnahan dan intensitas kehijauannya telah menurun. ${ }^{3}$ Persoalan lingkungan yang beragam ini bukanlah berasal dari takdir Tuhan semata, melainkan juga kerusakan yang bersifat antropogenik. Hal ini secara jelas telah dilegitimasikan Tuhan dalam Al-Qur'an:

"Telah tampak kerusakan di darat dan di laut disebabkan karena perbuatan tangan manusia; Allah menghendaki agar mereka merasakan sebagian dari (akibat) perbuatan mereka, agar mereka kembali (ke jalan yang benar)." (QS. Ar-Rum [30]: 41)

Jika dilihat dari kacamata spiritualitas, ditemukan bahwa krisis lingkungan global yang terjadi di berbagai belahan bumi pada hakikatnya disebabkan oleh adanya krisis spiritual. ${ }^{4}$ Manusia kurang menyadari adanya aturan perlakuan manusia terhadap lingkungan sekitarnya yang telah ditetapkan Allah dalam Al-Qur'an karena perannya sebagai khalifah di atas bumi. ${ }^{5}$ Al-Qur'an yang merupakan kitab petunjuk yang diturunkan Allah hadir untuk menanggulangi kecarut-marutan tatanan kehidupan manusia di atas bumi. Pelestarian, pemeliharaan serta pengelolaan lingkungan hidup dari segala bentuk pengrusakan merupakan pesan yang disampaikan Tuhan melalui

${ }^{1}$ Donald C. Cooper, Fundamentals of Search and Rescue, (Massachusetts: Jones and Bartlett Publisher, 2005), h. 58. Lihat juga United Nations Environment Programme, Earth and Faith: $A$ Book of Reflection for Action, (New York: UNEP Press, 2000), h. 78.

${ }^{2}$ Musțafā Sibā’̄ì, Ishtirākiyyah al-Islām, (Damaskus: Maṭba'ah Jāmi'ah Dimashqa, 1959), h. 69.

${ }^{3}$ Brian Arnold dkk., GCSE Core Science Foundation, (London: GCSE Press, 2006), h. 37-38.

${ }^{4}$ Sayyed Hossein Nasr, "Islam and the Environmental Crisis", dalam The Islamic Quaterly, Vol. 34, No. 4, 1994, h. 217-219. Lihat juga Richard Evanoff, "Reconciling Self, Society, and Nature in Environmental Ethics", dalam Capitalism, Nature, Socialism, Vol. 16, No. 3, 2006, h. 107; Gillian Rice, "Pro-environmenal Behavior in Egypt: Is There a Role for Islamic Environmental Ethics?", dalam Journal of Business Ethics, Vol. 65, 2006, h. 373.

${ }^{5}$ Khumaidi, Paradigma Sains Integratif al-Farabi: Pendasaran Filosofis bagi Relasi Sains, Filsafat dan Agama, (Jakarta: Sadra Press, 2015), h. 245.

42 | Al-Fanar: Jurnal Ilmu Al-Qur'an dan Tafsir 
sejumlah ayat yang terkandung dalam Al-Qur'an. Dari fenomena tersebut, paper ini mengungkap secara ringkas mengenai konsep environmentalisme dalam Al-Qur'an yang terdapat pada tafsir Al-Misbah, yang mewakili tipologi dari tafsir nusantara.

\section{BIOGRAFI M. QURAISH SHIHAB DAN TAFSIR AL-MISBAH}

Muhammad Quraish Shihab lahir 16 Februari 1944 di Lotassalo, Kabupaten Sidenreng Rappang (Sidrap), Sulawesi Selatan. Ayahnya merupakan seorang ahli tafsir yang juga merupakankeluarga terpelajar dari keturunan Arab, yaitu Prof. Abdurrahman Shihab.Ayahnya adalah seorang ulama dan guru besar dalam bidang tafsir dan dipandang sebagai salah satu tokoh pendidik yang bereputasi baik bagi kalangan masyarakat Sulawesi Selatan. ${ }^{6}$ Abdurrahman Shihab merupakan tamatan Jamiat Khair yang terkenal sebagai lembaga pendidikan Islam modern tertua di Indonesia. Beliau juga pernah menduduki jabatan Rektor IAIN Alauddin dan pendidik di Universitas Muslim Indonesia (UMI) di Ujung Pandang.

Pendidikan formal Quraish Shihab dimulai dari Sekolah Dasar di Ujung Pandang. Lalu melanjutkan studi menengahnya di daerah Malang, Jawa Timur sekaligus menempa pendidikan non formalnya di Pondok Pesantren Dar al-Hadits al-Faqihiyyah. Setelah selesainya pendidikan menengahnya, pada tahun 1958, ia berangkat ke Kairo, Mesir dan diterima di kelas II Tsanawiyyah al-Azhar. Pada 1967, ia mendapat gelar Lc (Licence) setelah menyelesaikan pendidikan S1 di Jurusan Tafsir dan Hadis, Fakultas Ushuluddin, Universitas al-Azhar. Kemudian dia melanjutkan studinya di Fakultas yang sama, dan pada 1969 meraih gelar MA spesialis bidang Tafsir Al-Qur'an dengan tesis yang berjudul al-I'jāz al-Tashrì' li Al-Qur'ān al-Karìm (Kemukjizatan al-Qur'an al-Karim dari Segi Hukum). ${ }^{7}$ Kemudian di usia 38, ia bisa menyelesaikan pendidikan doktornya dalam waktu dua tahun dengan predikat mumtāz ma'a martabat al-syaraf al-ūlā (summa cumlaude) pada tahun 1982 dengan disertasi Kitāb Naẓm al-Durar fi Tanāsub al-Āyāt wa al-Suwar li Ibrāhīm bin 'Umar al-Biqā'i (805-885 H): Tahqūq wa Dirāsah (al-An'ām wa al-A'rāf wa al-Anfāl). ${ }^{8}$

Sepulangnya ke Ujung Pandang, beliau dipercaya untuk menjabat Wakil Rektor Bidang Akademis dan Kemahasiswaan di Institut Agama Islam Negeri (IAIN) Alauddin, Ujung Pandang. Selain itu, jabatan lain di dalam kampus juga diberikan kepadanya seperti Koordinator Perguruan Tinggi Swasta Wilayah VII (Indonesia Bagian Timur) serta jabatan di luar kampus seperti Pembantu Pimpinan Kepolisisan Indonesia Timur dalam Bidang Pembinaan Mental.Kemampuan intelektual dan manajerialnya ini mengantarkannya menjadi Rektor Institut Agama Islam Negeri (kini UIN) Syarif Hidayatullah Jakarta selama dua periode.

Al-Misbah merupakan tafsir karangan beliau yang mulai dikerjakan saat di Kairo pada 18 Juni 1999. ${ }^{9}$ Penugasan B.J. Habibie kepadanya untuk menjadi Duta Besar di

\footnotetext{
${ }^{6}$ M. Quraish Shihab, Membumikan Al-Qur'an, (Bandung: Mizan, 1998), h. 6.

${ }^{7}$ Mauludin Anwar, dkk., Cahaya Cinta dan Canda, (Tangerang: Lentera Hati, 2015), h. 268.

${ }^{8}$ Syaifuddin dan Wardani, Tafsir Nusantara: Analisis Isu-Isu Gender dalam Al-Misbah Karya M.Quraish Shihab dan Tarjuman Al-Mustafid Karya 'Abd Al-Rauf Singkel, (Yogyakarta: LKiS, 2017), h. 43.

${ }^{9}$ Islah Gusmian, Khazanah Tafsir Indonesia: dari Hermeneutika hingga Ideologi, (Yogyakarta: LKiS, 2013), h. 108.
} 
Mesir, Somalia, dan Jibuti ternyata membawa berkah. "Kalau bukan karena Pak Habibie, mungkin Tafsir al-Mishbah tidak akan pernah terbit." berakhir pada tahun 2002, berhasil mengantarkannya untuk menyelesaikan 14 jilid. Sepulang ke Jakarta, beliau menuntaskan tulisannya pada jilid ke-15. Penyelesaian tulisan ini tepat pada hari Jumu'ah, 5 September 2003. Adapun metode yang digunakan dalam menafsirkan adalah metode tahlili. Sedangkan corak dari penafsirannya adalah al-Adabi al-Ijtimā'i.

\section{KONSEP ENVIRONMENTALISME}

Environmentalisme merupakan paham yang memiliki perhatian untuk menyelamatkan kekayaan alam dan melindungi ekosistem. ${ }^{11}$ Kepedulian terhadap alam ditunjukkan melalui perhatian yang lebih terhadap isu-isu pencemaran air dan udara, kepunahan spesies, gaya hidup rakus energi, ancaman perubahan iklim, rekayasa genetika dan lain sebagainya. Perspektif environmental didasari oleh adanya green movement, yaitu kesadaran bahwa perkembangan peradaban manusia memberikan dampak buruk bagi lingkungan. Pemikiran ini berasal dari fakta dari krisis lingkungan yang ada di masyarakat seperti pemanasan global, deforestasi dan limbah nuklir. Adapun pendekatan yang digunakan oleh para environmentalis adalah pendekatan liberal institusional, yaitu percaya bahwa institusi internasional dapat memberikan solusi terhadap masalah lingkungan yang dihadapi. ${ }^{12}$ Aspek utama konsep environmentalisme terdiri dari tiga, yaitu:

Environmentalisme sebagai suatu konsep yang berhubungan erat dengan falsafah alam sekitar. Falsafah alam sekitar yang dimaksudkan adalah pembahasan berkenaan hakikat sebenarnya hubungan manusia dan alam sekitar. Falsafah alam sekitar juga menjelaskan bagaimana sebenarnya perilaku yang harmoni terhadap alam sekitar dan bagaimana pula perilaku yang mengganggu keseimbangannya.

Environmentalisme adalah satu konsep yang berhubungan erat dengan perjuangan berasaskan ideologi alam sekitar. Ideologi merujuk kepada suatu doktrin yang diyakini oleh seseorang individu ataupun suatu kelompok yang menjadi dasar kepada kegiatan yang dilakukan. Perjuangan yang berasaskan ideologi alam sekitar ini berusaha menerapkan ideologi tersebut ke dalam pemikiran masyarakat luas sebagai agenda bertindak dalam lapangan kehidupan.

Environmentalisme adalah suatu konsep yang berhubungan erat dengan perancangan pengamanan alam sekitar. Dengan pengertian lain, environmentalisme merujuk kepada pihak berwenang berasaskan idealisme alam sekitar agar dilaksanakan di semua aspek.

\section{RELASI MANUSIA DENGAN ALAM}

Entitas ruang bagi makhluk hidup (manusia, hewan, dan tumbuhan) serta benda mati - udara, air, tanah, batu-batuan dan lain sebagainya - disebut sebagai lingkungan

\footnotetext{
${ }^{10}$ Mauludin Anwar, dkk., Cahaya Cinta dan Canda, h. 282.

${ }^{11}$ Gunnar Grenstad dkk., Unique Environmentalism: A Comparative Perspective, (New York: Springer, 2006), h. 1.

12 J. Michael Martinez, American Environmentalism: Philosophy, History, and Public Policy, (London: CRC Press, 2014), h. 249.
} 
hidup. ${ }^{13}$ Hubungan antara manusia dengan lingkungannya merupakan hubungan sirkular; keterkaitan dan timbal baliknya yang bersifat mutlak. Oleh karena itu, manusia disebut sebagai makhluk integral bagi lingkungannya. Dalam artian, ia dibentuk oleh lingkungan serta berperan juga untuk membentuk lingkungan hidupnya. Hubungan keduanya tidak berlangsung secara statis melainkan dinamis, dimana keterkaitannya berjalan secara sadar yang dapat dihayati dan dijadikan inti kepribadiannya, bukan penerimaan apa adanya tanpa dapat dipikirkan. ${ }^{14}$ Beberapa pandangan mengenai relasi manusia dan alam di antaranya:

\section{Antroposentris}

Pandangan ini dianggap sebagai faktor utama pembentuk watak eksploitatif manusia terhadap alam. ${ }^{15}$ Pandangan antroposentris berakar dari teks kitab suci agama monoteis yang menyakini bahwa bumi dan langit dicipta untuk mengabdi kepentingan manusia. ${ }^{16}$ White Jr. secara eksplisit menuding Kristianitas sebagai agama yang paling antroposentris bahwa manusia dipandang memiliki transendensi Tuhan; manusia diciptakan melalui citra Tuhan dan mewakili kekuasaan-Nya di muka bumi. Dengan demikian, pengeksploitasian alam untuk kesejahteraan manusia tidak lain karena kehendak Tuhan juga. ${ }^{17}$

\section{Dualistik}

Interpretasi agama dalam memandang dunia sangatlah memengaruhi bagaimana manusia memandang kedudukan dirinya terhadap alam dan Tuhannya. Sebagaimana dijelaskan oleh White Jr., teologi Judeo-Kristen menyebabkan manusia terpisah dari alam semesta, dimana manusia menganggap diri sebagai penguasa atau penakluk alam. Di samping itu, pandangan dualistik tentang alam semesta beserta manusia yang ada di dalamnya adalah terpisah dari Tuhan sebagai Penciptanya juga berasal dari tradisi agama-agama monoteis. Menurut banyak ahli, pandangan inilah yang menyebabkan manusia memandang dunia yang profan sehingga bisa dikeruk sesuka hati demi pembangunan dan kemakmuran manusia semata tanpa harus mempertimbangkan dampaknya bagi lingkungan secara global. ${ }^{18}$

\section{Orientasi Eskatologis}

Kisah penciptaan alam dalam kitab suci agama-agama monoteis yang berdampak pada perlakuan manusia atas lingkungan berkaitan dengan tujuan penciptaan alam semesta

${ }^{13}$ Philip Kristo, Ekologi Industri, (Yogyakarta: Andi, 2002), Cet. I, h. 29.

${ }^{14}$ Mujiono Abdillah, Agama Ramah Lingkungan Perspektif Al-Qur'an, (Jakarta: Paramadina, 2001), Cet. I, h. 145-146.

${ }^{15}$ Gary Steiner, Anthropocentrism and Its Discontents: The Moral Status of Animal in the History of Western Philosophy, (Pittsburgh: University of Pittsburgh, 2010), h. 52.

${ }^{16}$ Roger E. Timm, Dampak Ekologis Teologi Penciptaan Menurut Islam, Penerjemah P Hardono Hadi, (Yogyakarta: Kanisius, 2003), h. 109.

${ }^{17}$ Lynn White Jr., (eds.), Ecology and Religion in History, (New York: Harper and Row, 1974), h. 231.

${ }^{18}$ Muhammad Umer Chapra, Islam dan Tantangan Ekonomi, (Jakarta: Gema Insani Press, 2000), h. 129. 
dan manusia berorientasi eskatologis. Keyakinan dan ajaran agama yang berorientasi eskatologis, pada umumnya berdampak pada sikap dan perilaku penganut yang melalaikan lingkungan. ${ }^{19}$ Orientasi eskatologis yang dimaksud seperti pandangan bahwa kehidupan dunia ini laksana tempat mampir dan tempat mencari bekal untuk kehidupan mendatang. Kehidupan yang hakiki bukanlah di dunia ini melainkan di akhirat nanti.Kecenderungan yang lain adalah apa yang John Haught sebut sebagai "religiusitas apokaliptik". Sikap ini memandang bahwa alam semesta ini bersifat fana (tidak kekal) dan sedang mengarah kepada kehancuran. Sehingga jika memang sudah ditakdirkan untuk itu, manusia tidak perlu bersusah-payah untuk menyelamatkan bumi dari perusakan. Oleh karenanya, pandangan agama seperti ini tidak memiliki kepedulian terhadap lingkungan. ${ }^{20}$

John haught menyebut kecenderungan eskatologis semacam ini sebagai cosmic (terrestrial) homelessness (kosmos (bumi) bukan sebagai kediaman kita). Entitas manusia hanyalah sebagai orang asing bagi dunia. Doktrin semacam ini melahirkan dua hal berlawanan. Di satu sisi, pemahaman seperti dapat berbahaya bagi keberadaan lingkungan, namun di sisi lain, keyakinan ini bisa dikembangkan kea rah yang positif apabila dikaitkan dengan teori kosmologi Big Bang (Dentuman Besar). Teori ini menekankan bahwa alam semesta - termasuk di dalamnya manusia - sedang berada dalam perjalanan kosmik yang sangat panjang dan bersifat kontinyu. Idealisasi «sikaplepas bebas tanpa rumah» bisa digunakan secara bersamaan dengan teori tersebut sebagai kegelisahan religius (religious homelessness) dengan cara menenggelamkan diri manusia ke dalam perjalanan kosmik tersebut, bukan dengan membuat jarak dengan alam atau malah mengorbankan alam demi kegelisahan religius manusia. Hal ini disebabkan manusia juga merupakan milik dari alam semesta dan bumi ini. Sehingga apapun yang dialami kosmos, niscaya juga dialami oleh manusia. Menurut Haught, religious homelessness tidak sama dengan cosmic homelessness. Dengan kata lain, manusia tersesat bersama kosmos (lost with the cosmos) bukan tersesat dalam kosmos (lost in the cosmos). ${ }^{21}$

\section{Patriarkis (Perspektif Ekofeminisme)}

Gerakan ini lahir pada tahun 1974 yang pertama kali dicetuskan oleh seorang feminis Perancis, Francoise d'Eaubonne dalam buku Le Feminisme ou La Mort yang menggugah kaum perempuan untuk melakukan revolusi ekologis demi menyelamatkan lingkungan hidup. ${ }^{22}$ Ide ini berangkat dari penerimaan tuduhan White Jr terhadap teologi Judeo-Kristen, yang ditimbulkan dari kekeliruan penafsiran teks Bible, sebagai berwatak eksploitatif. Menurut Radford Ruether, penafsiran tersebut sangat dipengaruhi konteks dualistik alam dan manusia. Pemahaman ini berakar

${ }^{19}$ Roger E Timm, Dampak Ekologis Teologi Penciptaan ..., h. 111.

${ }^{20}$ John Haught, Perjumpaan Sains dan Agama: dari Konflik ke Dialog. Penerjemah Fransiskus Borgias, (Bandung: Mizan, 2004), h. 325.

${ }^{21}$ John Haught, Perjumpaan Sains dan Agama: dari Konflik ke Dialog. Penerjemah Fransiskus Borgias, (Bandung: Mizan, 2004), h. 325. John Haught, Perjumpaan Sains dan Agama, h. 333-334. Lihat juga John Haught, «Ecology: Restoring Our Sense of Belonging», dalam Woodstock Report, 38, Juni 1994

${ }^{22}$ A. Sonny Keraf, Etika Lingkungan Hidup, (Jakarta: PT Kompas Media Nusantara, 2010), h. 145.

46 | Al-Fanar: Jurnal Ilmu Al-Qur'an dan Tafsir 
dari pengaruh filsafat Yunani klasik tentang hubungan keterpisahan jiwa dan tubuh yang menjadi hubungan superior dan inferior. Tubuh atau materi diposisikan inferior terhadap jiwa; dan tubuh dianggap sebagai akar dari kejahatan moral. Pandangan ini kemudian memengaruhi dan membentuk hirarki sosial di mana superioritas jiwa atas perempuan, majikan atas budak, bangsa Yunani atas kaum Barbar dan seterusnya yang menunjukkan bahwa dominasi suatu kaum atas kaum yang lain menjadi sesuatu yang lumrah.Kemudian Radford Ruether mengkaitkan krisis ekologi yang terjadi dengan hirarki sosial. Ketika memahami kisah penciptaan alam dalam teks kitab suci, kelumrahan ini juga membentuk pandangan superioritas manusia untuk mendominasi alam semesta. Melalui gerakan ekofeminisnya, Radford Ruether menyerukan untuk merubah hirarki hubungan antara laki-laki dan perempuan, manusia dan alam semesta ke arah yang lebih setara karena keduanya saling memiliki ketergantungan dan saling memperngaruhi (biofeedback). ${ }^{23}$

Meskipun lebih terkenal karena dukungannya terhadap "pemitosan sains kembali" (remythifying science), Brian Swimme tampaknya bias juga digolongkan ke dalam ekofeminis. Gagasannya beranjak dari kenyataan bahwa sains tumbuh dari sikap penghormatan terhadap alam. Sebaliknya, pemikiran sains adalah mekanistik yang bersifat reduksionis. Dengan reduksionismenya, sains juga sangat didominasi oleh norma-norma dan pengalaman kelelakian. Sebagai contoh, teori asal-usul jagat raya lebih suka diistilahlan dengan teori Big Bang (Dentuman Besar) yang bernuansa maskulin dan bermetafora destruktif ketimbang memakai istilah, misalnya Cosmic Egg (Telur Jagat Raya) atau Superabundant Core (Inti Superpadat) yang memantulkan rasa kekaguman dan metafora kelahiran sesuatu. Menurut Swimme, inilah letak bias maskulin yang terkandung dalam sains. Oleh karenanya, ia mengusulkan memakai istilah puitis untuk penamaan sains, sehingga akan lebih menunjukkan rasa atau nuansa mulai dari kekaguman terhadap alam semesta, penghormatan akan kehidupan, sampai pandangan akan kehidupan kemanusiaan yang harmonis dengan segenap eksistensi alam. $^{24}$

\section{Nilai Intrinsik Alam}

Interpretasi mengenai ada tidaknya nilai intrinsik alam juga berkaitan dengan kisah penciptaannya dalam teks kitab suci agama monoteis. Dalam kitab tersebut, terdapat pemahaman bahwa makhluk selain manusia tidak memiliki nilai intrinsik. Pandangan semacam ini sangatlah umum di dunia modern. Alam dianggap sebagai sebuah mesin yang tidak memiliki nilai dan tujuan (no sense of purpose). Dasar lain dari pandangan ini adalah teori John Locke tentang kualitas primer dan sekunder. Menurutnya, alam hanya memiliki kualitas primer, karena alam dianggap tidak punya jiwa dan intelegensia sama sekali. Nilai sekunder akan hadir apabila mendapatkan intervensi dari manusia. Sebagai contoh, sebatang pohon atau kayu akan bernilai apanila dijadikan kursi, meja atau barang lainnya setelah dibentuk oleh manusia. Menurut Özdemir, pandangan semacam ini benar-benar menghilangkan kualitas inheren yang dimiliki oleh alam. ${ }^{25}$

\footnotetext{
${ }^{23}$ Denise Peeters, “Toward an Ecologically Informed Theology," dalam Theology Diges, Vol.40, No.1, 1993, h.113-114.

${ }^{24}$ Denise Peeters, "Toward an Ecologically...," h. 115.

25 Ibrahim Özdemir, "Toward an Understanding of Environmental Ethics from a Qur'anic Perspective", dalam Islam and Ecology, h. 5.
} 
Makhluk selain manusia hanya memiliki nilai instrumental bagi manusia karena mereka diciptakan hanya untuk melayani kepentingan manusia sedangkan manusia dipandang memiliki kedudukan paling tinggi di muka bumi. Pandangan ini dapat mengarah pada perlakuan yang kurang menghargai alam dan manusia merasa diberi hak mengatur lingkungannya sesuai selera mereka. ${ }^{26}$

\section{Kekerabatan Manusia dengan Makhluk Hidup}

Ian Barbour menjelaskan bahwa beberapa teori atau penemuan ilmu pengetahuan, seperti studi ekosistem dan ekologi, telah cukup banyak membuktikan adanya saling ketergantungan dan keterkaitan (interkoneksi) yang kompleks antar bentuk kehidupan di dunia ini. Sehingga pengetahuan juga bisa menumbuhkan kesadaran bahwa manusia benar-benar tidak dapat dilepaskan dari ketergantungan dan keterkaitannya dengan makhluk yang lain di dunia. Lebih jauh lagi, teori Biologi Evolusioner juga menunjukkan adanya kekerabatan manusia dengan semua makhluk. Oleh karena itu, teori ini dapat menumbuhkan kesadaran baru bagi manusia agar lebih menghormati makhluk lain yang memiliki sejarah asal-usul kosmik yang sama. ${ }^{27}$

Meskipun demikian, teori dan penemuan ilmu pengetahuan tersebut tetap akan mendapat tantangan dari para praktisi dan agamawan kreasionis. Kreasionisme sangat menentang teori evolusi dan meyakini bahwa manusia tidak memiliki kaitan asal-usul dengan spesies lain di dunia. ${ }^{28}$ Para kreasionis seringkali mendasarkan pendapatnya pada pemahaman kitab suci. Manusia dipandang sebagai makhluk yang paling sempurna dan paling tinggi kedudukannya daripada makhluk-makhluk lainnya. Secara teoretis, pandangan seperti ini menyimpan potensi watak eksploitatif terhadap lingkungan.

\section{ENVIRONMENTALISME DALAM TAFSIR AL-MISBAH}

Dari beberapa penafsiran M. Quraish Shihab terkait ayat-ayat lingkungan hidup, dapat ditemukan beberapa konsep yang ditujukan bagi manusia untuk menjaga lingkungan hidup. Gagasan ini melahirkan sebuah solusi untuk menjaga lingkungan hidup dengan melalui usaha pembuatanregulasi hukum; menjalin kerja sama antara pemerintah, perusahaan, masyarakat dan kalangan akademisi; memelihara sumber daya alam; reboisasi; serta ramah terhadap lingkungan.

\section{Pembuatan Regulasi Hukum}

Dalam QS. Āli Imrān [3]: 190-191, Allah swt telah mengajak manusia untuk berpikir dan melihat makna tersembunyi dari setiap keajaiban ciptaannya. Hal ini dikarenakan manusialah yang mendapatkan mandat dari Allah untuk menjadi khalifah di atas bumi, sebagaimana dijelaskan di QS. Al-Baqārah [2]: 30. penunjukan manusia sebagai khalifah bukanlah sebuah keputusan yang tanpa alasan atau suatu kebetulan, namun karena Allah mengetahui bahwa manusia mampu melaksanakannya. Sebagai

${ }^{26}$ Roger E Timm, "Dampak Ekologis Teologi Penciptaan menurut Islam", h. 110; Ibrahim Özdemir, "Toward an Understanding...", h. 5.

${ }^{27}$ Ian Barbour, Menemukan Tuhan dalam Sains Kontemporer dan Agama. Penerjemah Fransiskus Borgias, (Bandung: Mizan, 2005), h. 282-283.

${ }^{28}$ Adam Laats dan Harvey Siegel, Teaching Evolution in a Creation Nation, (Chicago: The University of Chicago Press, 2016), h. 57.

48 | Al-Fanar: Jurnal Ilmu Al-Qur'an dan Tafsir 
makhluk yang paling sempurna penciptaannya, manusia memiliki kelebihan dibandingkan dengan makhluk lain. ${ }^{29}$ Quraish menjelaskan lebih jauh lagi bahwa manusia memiliki potensi untuk mengetahui nama dan fungsi-fungsi benda alam sehingga mampu menyusun konsep-konsep, mencipta, mengembangkan dan mengemukakan gagasan, serta melaksanakannya sesuai dengan QS. Al-Baqārah [2]: 31. ${ }^{30}$

Namun, manusia juga perlu berhati-hati karena terdapat dua sifat dasar yang saling bertentangan dalam dirinya. Allah menjelaskan dalam QS. Al-Ma'ārij [70]: 19-21 mengenai keburukan manusia yang sering berkeluh kesah ketika menimpa kesusahan dan kikir ketika mendapat kebaikan. Keberadaan hawa nafsu dalam diri manusia juga perlu dikendalikan agar tidak terjerumus dalam kesesatan. Hal ini telah diperingatkan dalam QS. Al-A'rāf [7]: 176, Al-Kahfi [18]: 28, Țāhā [20]: 16, Al-Furqān [25]: 43, Al-Qașaș [28]: 50, dan Al-Jāthiyah [45]: 23. Entitas dua sifat yang berlawanan dala diri manusia ini lebih didominasi oleh potensi negatif yang dimiliki. Oleh karena itu, manusia perlu memelihara kesucian nafs dan tidak mengotorinya, agar mampu menarik potensi-potensi kebaikan dalam dirinya. ${ }^{31}$ Tugas kekhalifahan manusia didukung oleh fitrahnya sejak awal penciptaannya yang membawa potensi beragama yang lurus, dan dipahami oleh para ulama sebagai tauhid. Manusia yang berhasil memelihara kesucian nafs, menjaga fitrahnya sebagai hamba Allah yang bertauhid, mendorong dirinya untuk selalu berbuat baik serta meredam potensi-potensi negatif dalam dirinya maka merekalah yang dipilih Allah untuk menjadi penguasa di muka bumi, yang termaktub dalam QS, an-Nūr [24]: 55:

"Allah telah menjanjikan kepada orang-orang di antara kamu yang beriman dan yang berbuat baik, bahwa Dia sungguh akan menjadikan mereka berkuasa di bumi sebagaimana Dia telah menjadikan orang-orang sebelum mereka berkuasa dan sungguh Dia akan meneguhkan bagi mereka dengan agama yang telah Dia ridhai. Dan dia benar-benar mengubah (keadaan) mereka, setelah berada dalam ketakutan menjadi aman sentosa..."

Penafsiran ayat ini mengarah pada pemberian sebuah kekuasaan terhadap seseorang atas masyarakat yang dipimpinnya. Seorang pemimpin harus mampu mengambil kebijaksanaan yang tepat untuk membawa masyarakatnya menuju kesejahteraan. Janji Allah swt untuk memberi kekuasaan dan rasa aman hanya akan terlaksana bagi orang yang berhasil menjalankan petunjuk dan ketentuan-Nya. Dengan syarat iman, Allah akan mempermudah satu masyarakat melaksanakan sebab-sebab keberhasilan itu. ${ }^{32}$

Kata "Walayumakkinanna" pada ayat tersebut diambil dari kata "at-tamkīn" yang berarti penetapan suatu tempat tanpa adanya gangguan yang berarti. Hal ini mengisyaratkan bahwa penunjukkan manusia sebagai khalifah disertai dengan penempatannya di muka bumi mempertegas bahwa bumi merupakan tempat yang sangat baik dan cocok bagi manusia. Segala sarana yang dibutuhkan untuk mendukung kelangsungan hidup manusia telah disiapkan oleh Allah di dalamnya, karena Dia lah

${ }^{29}$ M. Quraish Shihab, Tafsir Al-Misbah: Pesan, Kesan dan Keserasian Al-Qur'an, (Jakarta: Lentera Hati, 2005), Vol. 1, h. 142.

${ }^{30}$ M. Quraish Shihab, Wawasan Al-Qur'an: Tafsir Maudhu>i atas Pelbagai Persoalan Umat, (Bandung: Mizan, 1996), h. 281.

${ }^{31}$ M. Quraih Shihab, Wawasan Al-Qur'an..., h. 285.

${ }^{32}$ M. Quraish Shihab, Tafsir Al-Misbah..., Vol. 9, h. 390. 
satu-satunya pemberi rizki. Sarana-sarana kehidupan lainnya seperti udara, cahaya, kehangatan dan lain-lain hanya berada dalam kekuasaan dan wewenang Allah swt. ${ }^{33}$ Hal ini telah diterangkan Allah dalam QS. Al-A'rāf [7]: 10 :

"Dan sungguh kami telah menempatkan kalian di bumi dan di sana telah kami sediakan (sumber) penghidupan untuk kalian. (Akan tetapi) sedikit sekali kalian yang bersyukur."

Namun, semua itu akan berubah sesuai dengan perlakuan manusia terhadapnya. Manusia memiliki hak untuk bertindak apapun serta memanfaatkan fasilitas apapun yang telah disediakan oleh Allah Swt di muka bumi ini dengan syarat tidak berlebihan. Sehingga perlu adanya sebuah peraturan terkait pengelolaan SDA agar tidak terjadi kegiatan eksploitatif yang dimunculkan manusia terhadap alam.

Tujuan dari terbentuknya regulasi hukum terkait pengelolaan SDA tidak lain adalah untuk mengatur tingkah laku manusia agar senantiasa melakukan kebaikan karena seorang khalifah dituntut untuk selalu berbuat baik. Sebagaimana dalam QS. an-Nūr [24]: 55 yang menyebutkan bahwa Allah swt memberikan kekuasaan kepada orang-orang yang beriman dan beramal saleh, yaitu orang-orang yang menjalankan petunjuk dan ketentuan-ketentuan-Nya. ${ }^{34}$ Demikian pula yang disebutkan dalam QS. alAn'ām [6]: 165. Anjuran bagi manusia untuk membuat hukum ialah guna mewujudkan keberhasilan menjalankan tugas kekhalifahan yang juga termaktub dalam QS. Fātị [35]: 39 dan QS. Hūd [11]: 85. Selain itu, pembuatan regulasi juga berfungsi untuk menguji keimanan manusia seperti yang tertera dalam QS. An-Naml [27]: 62. Karena sikap membangkang terhadap peraturan yang lahir dari keinginan mengikuti hawa nafsunya hanya akan mendatangkan kerugian dan kehancuran, baik bagi individu maupun masyarakat, seperti yang telah dijelaskan di QS.al-Mu'minūn [23]: 71.

\section{Kerjasama antara Pemerintah, Perusahaan, Masyarakat dan Akademisi}

Pengelolaan lingkungan hidup tidak dapat dilakukan secara mandiri, akan tetapi mengharuskan secara bergotong-royong sesuai dengan QS. Fāṭir [35]: 39. Hal ini dikarenakan keberadaan manusia yang bervariatif antara satu dengan yang lainnya, baik dari kecerdasan, status sosial, kemampuan dan potensi-potensi yang dimilikinya. Oleh karena itu, manusia dituntut untuk saling tolong-menolong dan saling memberi manfaat. ${ }^{35}$ Kehidupan sosial kemasyarakatan yang harmonis adalah kunci keberhasilan kerja sama. Berdasarkan QS. Al-A'rāf [7]: 56, menjaga lingkungan merupakan salah satu kewajiban harus dilakukan oleh manusia. Oleh karena itu, gotong royong harus diwujudkan dalam melaksanakan kewajibannya tersebut.

Dalam penafsirannya, Quraish tidak menyebutkan secara jelas pihak-pihak mana yang harus melakukan kerja sama. Namun, secara tersirat beliau menjelaskan bahwa kerja sama dalam rangka menyelamatkan lingkungan harus dilaksanakan secara berkelompok yang mencakup seluruh lapisan masyarakat. Pihak-pihak yang bertanggung jawab atas kerusakan lingkungan meliputi pemerintah, perusahaan (pelaku kegiatan industri) serta masyarakat umum. Selain itu, tidak lepas juga peran serta dari kalangan akademisi untuk

\footnotetext{
${ }^{33}$ M. Quraish Shihab, Tafsir Al-Misbah..., Vol. 7, h. 110-111.

${ }^{34}$ M. Quraish Shihab, Tafsir Al-Misbah..., Vol. 9, h. 390.

${ }^{35}$ M. Quraish Shihab, Wawasan Al-Qur'an..., h. 319.
} 
menjaga kelestarian lingkungan. Sebagai pemegang kekuasaan dalam sebuah negara, pemerintah memiliki posisi yang sangat strategis dalam menggerakkan masyarakat. Dalam artian, pemerintah memiliki kekuatan yang otoritatif dalam melaksanakan hukum, sehingga ia memiliki andil dalam pengendalian perilaku manusia. ${ }^{36}$

Allah Swt telah menjelaskan dalam QS. Āli 'Imrān [3]: 26 bahwa Dia telah melimpahkan sebagian kekuasaan-Nya kepada makhluk. Di antara mereka ada yang sukses dalam menjalankan tugas tersebut dengan baik karena mengikuti prinsip-prinsip kekuasaan politik yang diajarkan Allah dan adapula yang gagal. ${ }^{37}$ Kekuasaan politik dianugerahkan Allah kepada manusia melalui ikatan perjanjian yang berhubungan dua pihak, yaitu perjanjian dengan Allah swt dan dengan masyarakat yang dipimpinnya. ${ }^{38}$ Ikatan perjanjian baik yang terjalin kepada Allah maupun masyarakat yang dipimpinnya adalah sebuah amanah yang harus ditunaikan. Dalam QS. Șād [38]: 26, Allah telah memberikan contoh mengenai hal tersebut melalui kisah Nabi Daudas yang diangkat sebagai khalifah dan diperintahkan untuk berlaku adil di kalangan manusia. Oleh sebab itu, pemegang kekuasaan (pemerintah) harus menjalin kerja sama yang baik dengan seluruh lapisan masyarakat, baik yang berasal dari kalangan pelaku industri maupun dari masyarakat umum. Peraturan-peraturan tersebut harus mampu berkolabirasi dan sejalan dengan pihak-pihak terkait. Dalam hal ini, pemerintah Indonesia yang bertugas dan bertanggung jawab adalah Kementerian Lingkungan Hidup dan Kehutanan RI. Undang-Undang maupun peraturan yang dibuat bertujuan untuk mengontrol perilaku masyarakat, termasuk di dalamnya pelaku industri (perusahaan) dalam mengelola lingkungannya.

Selain itu, masyarakat yang merupakan makhluk sosial yang menggantungkan hidupnya pada keramahan lahan, alam dan lingkungan sekitarnya, maka dituntut pulauntuk memiliki inisiatif penyelamatan lingkungan. Kontribusi masyarakat dibutuhkan tanpa harus menunggu instruksi dari pemerintah. Masyarakat berhak membuat kelembagaan yang berkonsentrasi pada aksi penyelamatan alam dengan memiliki prinsip keefektifan individual dan kolektif, saling menghormati, komunikatif, bertanggung jawab dalam mengembangkan kontrol internal, serta memiliki keputusan yang mengikat untuk dilaksanakan. ${ }^{39}$

Dalam mengatasi problematika lingkungan, perlu adanya kalangan akademisi untuk mengakomodir dan mencarikan jalan keluar terkait pemanfaatan alam dan pelestariannya. Penciptaan alam raya secara sempurna adalah salah satu tanda kekuasaan Allah yang harus dimengerti dan dipikirkan oleh manusia sebagaimana dijelaskan dalam QS. Āli 'Imrān [3]: 190-191. Hukum-hukum alam yang melahirkan kebiasaan-kebiasaan pada hakikatnya ditetapkan dan diatur oleh Allah Yang Maha Mengetahui dan Maha Mengelola Segala Sesuatu. ${ }^{40}$ Kalangan akademisi, khususnya yang berkecimpung di bidang lingkungan memiliki tugas untuk membagikan pengetahuannya kepada

\footnotetext{
${ }^{36}$ M. Quraish Shihab, Wawasan Al-Qur'an..., h. 514.

${ }^{37}$ M. Quraish Shihab, Wawasan Al-Qur'an..., h. 415.

${ }^{38}$ M. Quraish Shihab, Wawasan Al-Qur'an..., h. 418.

39 Transtoto Handadhari, Kepedulian yang Terganjal: Menguak Belantara Permasalahan Kehutanan Indonesia, (Jakarta: Elex Media Kompetindo, 2009) h. 159.

${ }^{40}$ M. Quraish Shihab, Tafsir Al-Misbah..., Vol. 2, h. 291.
} 
khalayak umum sekaligus kepada pemerintah agar dapat mengambil keputusan yang tepat mengenai persoalan lingkungan. Sehingga kerja sama antara pemerintah, perusahaan, masyarakat dan kalangan akademisi adalah sebuah keharusan yang tidak dapat dihindari.

\section{Memelihara Sumber Daya Alam}

Dalam menjalani kehidupan, segala upaya akan dilakukan manusia untuk mencapai tujuannya. Mereka tidak menghiraukan fakta bahwa segala sesuatu cenderung menua dan musnah. ${ }^{41}$ Namun, dalam pelaksanaannya kerap kali mengabaikan dampak buruk yang akan terjadi di kemudian hari. Budaya eksploitasi sumber daya alam menyebabkan kekacauan ekosistem yang hampir terjadi di seluruh penjuru dunia, baik di darat maupun di laut. Sebagaimana firman Allah dalam QS. Ar-Rūm [30]: 41 yang menyebutkan bahwa seluruh kerusakan alam baik di darat maupun di laut adalah akibat dari perbuatan manusia. Allah secara jelas melarang manusia beruat kejahatan di muka bumi dengan menjadi perusak seperti yang diterangkan dalam QS. Al-Baqārah [2]: 60. Dalam bermuamalah, manusia dituntut untuk berbuat adil dalam hal apapun agar tercipta kesejahteraan dan kenyamanan hidup, karena dengan kesegeraan mengikuti hawa nafsu tidak akan menghasilkan apapun kecuali perusakan. Hal ini bermakna pula dilarang untuk melakukan perusakan dengan sengaja. ${ }^{42}$ Sedangkan Allah sendiri tidak menyukai pembuat kerusakan. ${ }^{43}$

Sumber daya alam sendiri tidak semuanya dapat diperbaharui, tetapi juga ada yang tidak dapat diperbaharui.Sumber daya alam yang dapat diperbaharui selalu dapat dimanfaatkan oleh makhluk hidup dalam jangka waktu yang panjang karena manusia mampu mengusahakannya. Sementara suber daya alam yang tidak dapat diperbarui akan mengalami penurunan jumlah hingga pada akhirnya akan habis dimanfaatkan oleh makhluk hidup. ${ }^{44}$ Meskipun demikian, sumber daya alam yang dapat diperbaharui juga akan mengalami kepunahan, apabila tidak ada upaya dari pihak konsumen untuk melakukan pembaharuan. Berbagai kegiatan industrial yang berorientasi pada pengambilan keuntungan sebesar-besarnya tanpa memperdulikan kehidupan generasi setelahnya adalah salah satu contoh kegiatan yang memperpendek usia sumber daya alam tersebut. Segala sarana yang telah disediakan untuk kebutuhan makhluk di muka bumi tidak akan kekal selamanya. Sumber daya alam, atau yang di dalam QS. Al-A'rāf [7]: 24 dan QS. An-Nāzi'āt [79]: 33 disebut dengan matā' adalah sebuah kesenangan yang memiliki sifat mudah diperoleh namun mudah lenyap. Seluruh kekayaan sumber daya alam adalah matā' yang bersifat sementara. Suatu saat Allah akan mengembalikannya kembali sesuai dengan kehendak-Nya.

Dalam QS. Ash-Shu'arā' (26): 151-152 terdapat makna secara tersirat bahwa sifat berlebihan yang hinggap pada diri manusia merupakan pemicu timbulnya sikap ketidakpedulian pada lingkungan. Padahal dalam QS. Gāfir [40]: 57 dijelaskan bahwa penciptaan langit dan bumi itu lebih rumit daripada penciptaan manusia. Dengan

${ }^{41}$ M. Thalhah dan Ahmad Mufid, Fikih Ekologi: Menjaga Bumi Memahami Makna Kitab Suci, (Yogyakarta: Total Media, 2008), h. 39.

${ }^{42}$ M. Quraish Shihab, Tafsir Al-Misbah..., Vol. 6, h. 313.

${ }^{43}$ M. Quraish Shihab, Tafsir Al-Misbah..., Vol. 10, h. 405.

${ }^{44}$ Suwarno dan Hotimah, Serba Tahu tentang Sains Ilmu Pengetahuan Alam, (Yogyakarta: Tugu, 2009), h. 186. 
demikian, manusia tidak pantas untuk bersikap sombong dan melampaui batas, karena manusia tidak akan sanggup menguasai bumi tanpa izin dari Allah swt. Sikap boros dan eksploitasi berlebihan menyebabkan kerusakan alam dan menimbulkan bencana, seperti pemiskinan kesuburan tanah dengan turunnya produktivitas pertanian, banjir, longsor, kekeringan, kebakaran hutan maupun lahan dan lain sebagainya. Penggunaan energi secara berlebihan juga memperburuk kondisi sumber daya alam yang tersisa. Manusia tidak boleh bersikap apatis terhadap hal ini, karena apabila perusakan yang terjadi dibiarkan begitu saja maka akan menyebar ke semua lingkungan hidup. ${ }^{45}$

\section{Reboisasi}

Maraknya pembalakan hutan secara liar menimbulkan kerusakan di permukaan bumi yang berakibat hilangnya fungsi utama hutan sebagai paru-paru dunia. Pengalih fungsian lahan hutan menjadi area pertanian dan perkebunan, bahkan menjadi area industri serta pengambilan hasil hutan dan pembukaan lahan yang kurang mengindahkan kelestarian hutan akan berdampak buruk bagi masyarakat. udara semakin kotor dan berdebu akibat perubahan hutan menjadi kota, penebangan pohon-pohon, pembangunan gedunggedung pencakar langit, penutupan sawah menjadi beton. Dan aktivitas lain yang tidak terkontrol. ${ }^{46}$ Berdasarkan QS. An-Nūr [24]: 55, Quraish mengemukakan bahwa seorang khalifah harus mampu berbuat baik dan membawa kesejahteraan bagi seluruh makhluk. Salah satu langkah yang harus ditempuh untuk mewujudkan kesejahteraan tersebut adalah mengadakan perbaikan pada bumi yang rusak. Dalam QS. Al-Baqārah [2]: 164 disebutkan Allah swt telah menghidupkan bumi. Oleh karena itu, menghidupkan kembali bumi yang telah gersang adalah tanggung jawab manusia sebagai wakil Allah di bumi. Peringatan bagi manusia untuk tidak membuat kerusakan di muka bumi sudah diterangkan dalam QS. Al-A'rāf [7]: 56 dan QS. Al-Qaṣaṣ [28]: 77.

Dalam QS. Ibrāhīm [14]: 32-33, Allah menunjukkan bahwa Dia telah menciptakan langit dan bumi serta mengatur peredarannya, kemudian menurunkan air hujan untuk menumbuhkan buah-buahan sebagai rezeki yang dapat dimanfaatkan oleh makhluk yang berada di bumi. Selain itu, Allah juga telah menundukkan lautan dan sungai agar dapat memberikan manfaatnya kepada manusia. ${ }^{47}$ Selain itu, dalam QS. Al-Furqān [25]: 48-49, Allah menjelaskan di antara kekuasaan-Nya ialah dengan mengirimkan angin untuk menggiring awan sebagai pembawa kabar gembira sebelum kedatangan rahmat-Nya yaitu ketika sebelum turunnya hujan, lalu diturunkanlah hujan dari langit yang berasal dari air yang sangat suci dan amat bersih, serta dapat digunakan untuk menyucikan agar dengan air yang telah diturunkan dapat menghidupkan tanah gersang yang mati sehingga tumbuh subur. Selain itu, air yang turun juga digunakan untuk minum bagi binatang-binatang ternak dan manusia yang banyak. ${ }^{48}$ Dari dua penjelasan yang terdapat dalam dua surat tersebut, terbesit isyarat untuk mengembalikan fungsi hutan atau reboisasi. Reboisasi tidak harus dilakukan di hutan yang telah gundul, namun di manapun tempatnya dapat dilakukan reboisasi. Di beberapa tempat seperti

\footnotetext{
${ }^{45}$ M. Quraish Shihab, Tafsir Al-Misbah..., Vol. 1, h. 126.

${ }^{46}$ Valerina Daniel, Easy Green Living: Langkah Mudah Menyelamatkan Bumi dari Kisah-Kisah Inspiratif Seorang Duta Lingkungan, (Jakarta: Hikmah, 2009), h. xv.

${ }^{47}$ M. Quraish Shihab, Tafsir Al-Misbah..., Vol. 7, h. 61.

${ }^{48}$ M. Quraish Shihab, Tafsir Al-Misbah..., Vol. 9, h. 491.
} 
kantor-kantor, sekolah-sekolah, maupun tempat umum lainnya telah melakukan upaya penghijauan. Gedung-gedung diperkotaan juga tetap harus memperhatikan kondisi lingkungan dengan menyediakan lahan penghijauan. Demikianlah langkah-langkah kecil yang dapat dilakukan untuk menghidupkan kembali bumi yang mulai gersang ini.

\section{Ramah Terhadap Lingkungan}

Teori ramah lingkungan secara implisit telah disebutkan dalam QS. An-Naml [27]: 61. Kemudian disebutkan juga di dalam QS. Al-Baqārah [2]: 164, QS. Ibrāhīm [14]: 32 dan QS. Al-Jāthiyah [45]: 12 yang mencontohkan kapal sebagai kendaraan yang dapat dimanfaatkan oleh manusia. Serta masih banyak lagi ayat yang menjelaskan penggunaan kapal dalam suatu kisah Nabi, seperti QS. Al-A'rāf [7]: 64, QS. Yūnus [10]: 22 dan 73, QS. Hūd [11]: 37-38, QS. An-Nahl [16]: 14, QS. Al-'Ankabūt [29]: 65 , dan masih banyak lagi lainnya. Penggunaan kapal di sini dimaksudkan bahwa kendaraan yang disediakan untuk manusia adalah kendaraan yang ramah terhadap lingkungan, tidak menghasilkan kotoran maupun polusi. Ayat selanjutnya adalah QS. Al-Hadīd [57]: 20 yang mengemukakan tentang sikap bermegah-megahan dan mengumpulkan banyak harta secara tidak langsung akan mengakibatkan kekeringan dan berbagai bencana yang lain. Hal ini sejalan dengan QS. Al-Baqārah [2]: 11-12 yang menerangkan bahwa manusia secara tidak disadari telah melakukan perusakan di bumi.

Upaya ramah lingkungan dapat dilakukan melalui perencanaan kawasan kegiatan industri dan teknologi sehingga kebutuhan antara keperluan untuk kegiatan industri dan teknologi dengan keperluan pemukiman di sekitarnya dapat diatur tanpa merugikan salah satu pihak. ${ }^{49}$ Selain itu, pengatiran dan pengawasan kegiatan juga perlu dilakukan. Hla terpenting dalam upaya ramah lingkungan adalah menumbuhkan perilaku disiplin. ${ }^{50}$ Sikap ramah lingkungan harus ditunjukkan dalam kehidupan sehari-hari. Segala aktivitas yang menyebabkan polusi harus dihindari sebisa mungkin. Bagi pihak yang bergerak di bidang industrial, pembuangan limbah juga harus diawasi secara ketat guna menjauhkan dari adanya pencemaran lingkungan.

\section{PENUTUP}

Dalam tafsir al-Mișbāh, terdapat konsep environmentalisme secara implisit yang digagas M. Quraish Shihab melalui penafsiran ayat-ayat tentang lingkungan hidup. Menurutnya, faktor utama dari problematika ekologis yang marak terjadi adalah lalainya dan interpretasi yang tidak komprehensif dari manusia sebagai makhluk yang diamanahkan sebagai khalifah di muka bumi. Aspek utama dalam konsep environmentalisme juga termuat di dalam tafsirnya, yang terdiri dari memahami falsafah alam melalui relasi manusia dan lingkungan; menggunakan ideologi dasar dengan cara mempelajari hukum-hukum alam (sunnatullah); serta melakukan usaha perlindungan alam dari kerusakan. Adapun gagasan tersirat dalam usaha menciptakan keseimbangan adalah melalui usaha pembuatan regulasi hukum; menjalin kerja sama antara pemerintah, perusahaan, masyarakat dan kalangan akademisi; memelihara sumber daya alam; reboisasi; serta ramah terhadap lingkungan.

\footnotetext{
49 Wisnu Arya Wardhana, Dampak Pencemaran Lingkungan, (Yogyakarta: Andi Offset, 1995), h. 163 .

${ }^{50}$ Wisnu Arya Wardhana, Dampak Pencemaran Lingkungan, h. 165.
} 


\section{DAFTAR PUSTAKA}

Abdillah, Mujiono. Agama Ramah Lingkungan Perspektif Al-Qur'an, Jakarta: Paramadina, 2001, Cet. I.

Anwar, Mauludin, dkk. Cahaya Cinta dan Canda, Tangerang: Lentera Hati, 2015.

Arnold, Brian, dkk. GCSE Core Science Foundation, London: GCSE Press, 2006.

Barbour, Ian. Menemukan Tuhan dalam Sains Kontemporer dan Agama. Penerjemah Fransiskus Borgias, Bandung: Mizan, 2005.

Chapra, Muhammad Umer. Islam dan Tantangan Ekonomi, Jakarta: Gema Insani Press, 2000.

Cooper, Donald C. Fundamentals of Search and Rescue, Massachusetts: Jones and Bartlett Publisher, 2005.

Daniel, Valerina. Easy Green Living: Langkah Mudah Menyelamatkan Bumi dari KisahKisah Inspiratif Seorang Duta Lingkungan, Jakarta: Hikmah, 2009.

Evanoff, Richard. "Reconciling Self, Society, and Nature in Environmental Ethics", dalam Capitalism, Nature, Socialism, Vol. 16, No. 3, Pp. 107-114, 6 Agustus 2006. https://doi.org/10.1080/10455750500208839

Gusmian, Islah. Khazanah Tafsir Indonesia: dari Hermeneutika hingga Ideologi, Yogyakarta: LKiS, 2013.

Grenstad, Gunnar dkk. Unique Environmentalism: A Comparative Perspective, New York: Springer, 2006.

Handadhari, Transtoto. Kepedulian yang Terganjal: Menguak Belantara Permasalahan Kehutanan Indonesia, (Jakarta: Elex Media Kompetindo, 2009.

Haught, John. Perjumpaan Sains dan Agama: dari Konflik ke Dialog. Penerjemah Fransiskus Borgias, Bandung: Mizan, 2004.

. "Ecology: Restoring Our Sense of Belonging", dalam Woodstock Report, Vol.38, Juni 1994.

Keraf, A. Sonny. Etika Lingkungan Hidup, Jakarta: PT Kompas Media Nusantara, 2010.

Khumaidi, M. Paradigma Sains Integratif al-Farabi: Pendasaran Filosofis bagi Relasi Sains, Filsafat dan Agama, Jakarta: Sadra Press, 2015.

Kristo, Philip,Ekologi Industri, Yogyakarta: Andi, 2002, Cet. I.

Laats, Adam dan Harvey Siegel, Teaching Evolution in a Creation Nation, Chicago: The University of Chicago Press, 2016.

Martinez, J. Michael, American Environmentalism: Philosophy, History, and Public Policy, London: CRC Press, 2014.

Nasr, Sayyed Hossein. "Islam and the Environmental Crisis", dalam The Islamic Quaterly, Vol. 34, No. 4, 1 Januari 1990.

Özdemir, Ibrahim. "Toward an Understanding of Environmental Ethics from a Qur`anic Perspective", dalam Islam and Ecology.

Peeters, Denise. "Toward an Ecologically Informed Theology," dalam Theology Diges, Vol.40, No.1, 1993. 
Rice, Gillian. "Pro-environmenal Behavior in Egypt: Is There a Role for Islamic Environmental Ethics?", dalam Journal of Business Ethics, Vol. 65, 2006.

Shihab, M. Quraish. Membumikan Al-Qur'an, Bandung: Mizan, 1998. . Tafsir al-Misbah: Pesan, Kesan dan Keserasian al-Qur'an, Jakarta: Lentera Hati, 2005.

. Wawasan Al-Qur'an: Tafsir Maudhu>i atas Pelbagai Persoalan Umat, Bandung: Mizan, 1996.

Sibā'īy, Musțafā. Ishtirākiyyah al-Islām, Damaskus: Maṭba'ah Jāmi'ah Dimashqa, 1959.

Steiner, Gary. Anthropocentrism and Its Discontents: The Moral Status of Animal in the History of Western Philosophy, Pittsburgh: University of Pittsburgh, 2010.

Suwarno dan Hotimah. Serba Tahu tentang Sains Ilmu Pengetahuan Alam, Yogyakarta: Tugu, 2009.

Syaifuddin dan Wardani. Tafsir Nusantara: Analisis Isu-Isu Gender dalam Al-Mishbah Karya M.Quraish Shihab dan Tarjuman Al-Mustafid Karya 'Abd al-Rauf Singkel, Yogyakarta: LKiS, 2017.

Thalhah, Muhammad, dan Ahmad Mufid. Fikih Ekologi: Menjaga Bumi Memahami Makna Kitab Suci, Yogyakarta: Total Media, 2008.

Timm, Roger E. Dampak Ekologis Teologi Penciptaan Menurut Islam. Penerjemah P Hardono Hadi, Yogyakarta: Kanisius, 2003.

United Nations Environment Programme. Earth and Faith: A Book of Reflection for Action, New York: UNEP Press, 2000.

White Jr., Lynn, (eds.). Ecology and Religion in History, New York: Harper and Row, 1974.

Wardhana, Wisnu Arya. Dampak Pencemaran Lingkungan, Yogyakarta: Andi Offset, 1995 